\title{
The effects of fipronil and the photodegradation product fipronil desulfinyl on growth and gene expression in juvenile blue crabs, Callinectes sapidus, at different salinities
}

\author{
Andrew D. Goff ${ }^{a}$, Parichehr Saranjampour ${ }^{b}$, Lauren M. Ryan ${ }^{a}$, Michelle L. Hladik ${ }^{c}$, \\ Joseph A. Covi ${ }^{a}$, Kevin L. Armbrust ${ }^{b}$, Susanne M. Brander ${ }^{a, *}$ \\ a Department of Biology and Marine Biology, University of North Carolina Wilmington, 601 S. College Road, Wilmington, NC 28401, USA \\ ${ }^{\mathrm{b}}$ Department of Environmental Sciences, College of the Coast and Environment, Louisiana State University, Energy, Coast E Environment Building, \\ Baton Rouge, LA 70803, USA \\ c U.S. Geological Survey, California Water Science Center, 6000 J St, Placer Hall, Sacramento, CA 95819, USA
}

\section{A R T I C L E I N F O}

\section{Article history:}

Received 7 January 2017

Received in revised form 24 February 2017

Accepted 25 February 2017

Available online 28 February 2017

\section{Keywords:}

Crustacean

Decapod

Endocrine disruption

Fipronil

Fipronil desulfinyl

Salinity

Ecdysone receptor

Vitellogenin

\begin{abstract}
A B S T R A C T
Endocrine disrupting compounds (EDCs) are now widely established to be present in the environment at concentrations capable of affecting wild organisms. Although many studies have been conducted in fish, less is known about effects in invertebrates such as decapod crustaceans. Decapods are exposed to low concentrations of EDCs that may cause infertility, decreased growth, and developmental abnormalities. The objective herein was to evaluate effects of fipronil and its photodegradation product fipronil desulfinyl. Fipronil desulfinyl was detected in the eggs of the decapod Callinectes sapidus sampled off the coast of South Carolina. As such, to examine specific effects on C. sapidus exposed in early life, we exposed laboratory-reared juveniles to fipronil and fipronil desulfinyl for $96 \mathrm{~h}$ at three nominal concentrations $(0.01,0.1,0.5 \mu \mathrm{g} / \mathrm{l})$ and two different salinities $(10,30 \mathrm{ppt})$. The size of individual crabs (weight, carapace width) and the expression of several genes critical to growth and reproduction were evaluated. Exposure to fipronil and fipronil desulfinyl resulted in significant size increases in all treatments compared to controls. Levels of expression for vitellogenin (Vtg), an egg yolk precursor, and the ecdysone receptor (EcR), which binds to ecdysteroids that control molting, were inversely correlated with increasing fipronil and fipronil desulfinyl concentrations. Effects on overall growth and on the expression of EcR and Vtg differ depending on the exposure salinity. The solubility of fipronil is demonstrated to decrease considerably at higher salinities. This suggests that fipronil and its photodegradation products may be more bioavailable to benthic organisms as salinity increases, as more chemical would partition to tissues. Our findings suggest that endocrine disruption is occurring through alterations to gene expression in $C$. sapidus populations exposed to environmental levels of fipronil, and that effects may be dependent upon the salinity at which exposure occurs.
\end{abstract}

() 2017 Elsevier B.V. All rights reserved.

\section{Introduction}

The anthropogenic addition of nutrients, pesticides, wastewater, and other persistent pollutants is impacting organisms inhabiting rivers, estuaries, and coastal waters throughout the world (Ridgway and Shimmield, 2002; Lintelmann et al., 2003; Connon et al., 2012). Over the past several decades, intensification of agriculture, the growth of concentrated animal feeding operations, changes in the population density of communities

\footnotetext{
* Corresponding author. Tel.: +1 9109623786.

E-mail address: branders@uncw.edu (S.M. Brander).
}

surrounding estuaries, and increased coverage by impervious surfaces have drastically altered the surface water runoff entering aquatic communities (Mallin et al., 2009; Viehman et al., 2011; Griffin et al., 2013). These pollutants are washed into waterways to an extent that we have only begun to quantify over the last few decades, with a focus on those that act as endocrine disrupting compounds (EDCs) in sensitive non-target organisms (Benotti et al., 2008; Bonmatin et al., 2015). EDCs mimic or interfere with the endogenous hormones that regulate and maintain routine physiological and behavioral functions (Brander, 2013). As such they compromise responses to environmental conditions and cause complications affecting many of the biological processes within an organism, often by activating or blocking hormone reception 
sites associated with growth, reproduction, and neuronal activity (Segner et al., 2003; Oetken et al., 2004; Petrovic et al., 2004). Invertebrates rely on hormonal cues (i.e. ecdysteroids) to regulate growth and reproduction, making them susceptible to EDCs.

Pesticides are one of many classes of compounds considered to disrupt endocrine function, and they can become more persistent upon entering aquatic systems since they often possess hydrophobic properties and therefore increased affinity for sediments or tissues (Islam and Tanaka, 2004; Weston et al., 2015). Since both insects and crustaceans are members of Arthropoda, crustaceans are highly susceptible to the effects of chemicals used to kill insects (terrestrial arthropods) due to their similar physiology (LeBlanc, 2007). Endocrine disruptor effects are well documented for amphibians and fish (Carr and Patiño, 2011; Kime, 2012; Brander et al., 2016a), but are understudied in crustaceans, particularly those living in estuarine ecosystems (Oetken et al., 2004). As such, establishing a link between EDCs in estuaries and the health of crustacean communities will provide insights into the current status of and potential threats to these populations by helping to identify the mechanisms at work.

North Carolina's largest, most profitable fishery is Callinectes sapidus. Over the past decade, this fishery has declined to historically low levels, with a 20\% reduction in catch in 2013 from the ten-year average (NCDMF, 2016). There are many potential causes for this decline, such as stock recruitment, fishing effects, climate change, species range shifts, and exposure to EDCs or other persistent pollutants (Lipcius and William, 2002; Lee and Frischer, 2004). The range of salinities, habitats, and the importance to food web dynamics of $C$. sapidus make the implications of endocrine disruption to this species applicable to a wide variety of ecological considerations.

Terrestrially applied pesticides, which comprise a large percentage of non-point source runoff from agricultural and urban use, enter estuaries and are capable of causing significant damage to invertebrate communities (Fulton et al., 1999; Weston and Lydy, 2014). Fipronil, a phenylpyrazole introduced in 1996, is now commonly used for control of fire ants, cockroaches, beetles, and termites and is also the active ingredient in flea and tick treatments for dogs and cats. Fipronil functions by interfering with the central nervous system through hyper excitation of GABA channels rendering insects paralyzed (Gunasekara et al., 2007). While fipronil is not particularly acutely toxic to vertebrates, it is capable of affecting crustaceans at low concentrations (Konwick et al., 2005; Key et al., 2003). Fipronil's major photoproduct, fipronil desulfinyl, is formed when fipronil is exposed to ultraviolet (UV) light (Walse et al., 2004). Fipronil desulfinyl may have a longer residence time in aquatic environments because it is less reactive than fipronil, slower to photolyze in solution, is stable towards photolysis on leaf surfaces, and has a $\log K_{\text {ow }}$ value of 4.2 versus fipronil's $\log K_{\text {ow }}$ value of 4.0 (Walse et al., 2004). Herein we show that fipronil desulfinyl (produced by exposure to UV light), but not the parent compound fipronil, was detected in the eggs of wild female C. sapidus sampled off the coast of South Carolina.

Increased salinity is established to decrease the water solubility and consequently increase the partitioning of organic compounds into adjacent environmental compartments such as biota, particulate matter, sediment, and air (Noubigh et al., 2007; Saranjampour et al., 2017). The salinity impact is magnified for more hydrophobic chemicals (Turner and Rawling, 2001), such as fipronil and its photodegradation products. As such, the ramifications of exposure to fipronil and its photoproduct fipronil desulfinyl in organisms such as $C$. sapidus at different salinities was in need of further evaluation.

Given that fipronil desulfinyl was detected in C. sapidus eggs, and because juvenile blue crabs are established to be highly sensitive to pesticides (Osterberg et al., 2012), juvenile blue crabs were selected as test organisms in this investigation. Fipronil has also been shown to interfere with endocrine function in crustaceans (e.g. Wirth et al., 2004; Gaertner et al., 2012). As such, the objective of this investigation was to determine the effects of the insecticide fipronil and its photodegradation product fipronil desulfinyl, on gene expression and growth in recently metamorphosed juvenile blue crabs. Given previous findings in crustaceans and current knowledge of decapod endocrinology (Wirth et al., 2004; Chandler et al., 2004; Chang and Mykles, 2011; Gaertner et al., 2012; Techa et al., 2015) we hypothesized that fipronil and fipronil desulfinyl would cause alterations in the expression of genes for the egg yolk precursor vitellogenin (Vtg), the molt-controlling ecdysone receptor (EcR), molt inhibiting hormone (MIH), and the retinoic acid receptor (RXR), which dimerizes with EcR to influence transcription. All are involved in the regulation of growth and reproduction. We also hypothesized that the growth of juveniles would be affected, and that observed effects may differ depending upon the exposure to salinity. To the best of our knowledge, this is the first study to evaluate the effects of fipronil and the common photodegradation product fipronil desulfinyl in recently metamorphosed juvenile crustaceans, and the first study of its kind in C. sapidus.

\section{Methods}

\subsection{Megalopae rearing}

C. sapidus megalopae (10-15 dph; days post hatch) acquired from the Institute of Marine and Environmental Sciences (IMET) at the University of Maryland (UMD) were acclimated for $6 \mathrm{~h}$ in $25 \mathrm{ppt}$ artificial seawater (ASW) at room temperature. Individuals were then placed individually in $2.4 \mathrm{ml}$ glass-coated wells in a 96 well-plate, in 25 ppt ASW maintained at $20 \pm 1^{\circ} \mathrm{C}$ for a period until they metamorphosed to juveniles ( $\sim 25 \mathrm{dph})$. Megalopae were fed live brine shrimp (Artemia franciscana) coated in Selcon ad libitum twice a daily. Seventy percent water changes were performed three times per day to minimize accumulation of ammonia and maintain dissolved oxygen content. Following metamorphosis, juvenile crabs were maintained in $10 \mathrm{ml}$ glass beakers at the water conditions described above until the week prior to being used for fipronil and fipronil desulfinyl exposures. At this time, juveniles were acclimated over a period of multiple days to a salinity of either $10 \mathrm{ppt}$ or $30 \mathrm{ppt}$, gradually stepping down salinity 3-4 ppt per day.

\subsection{Laboratory exposures}

Crabs recently metamorphosed from the megalopae stage were exposed to fipronil and fipronil desulfinyl individually (not as a mixture) at a range of $n g-\mu g$ concentrations at two different salinities (10, $30 \mathrm{ppt})$. Treatments were: methanol control, low nominal $0.01 \mu \mathrm{g} / \mathrm{L}$ (environmentally relevant), medium nominal concentration $0.1 \mu \mathrm{g} / \mathrm{l}$ (rare but possible in the environment), and a high nominal concentration $0.5 \mu \mathrm{g} / \mathrm{l}$ (effective concentration but not lethal based on other studies). Stock solutions of fipronil (Chem Services, West Chester, PA, USA) or fipronil desulfinyl (Toronto Research Chemicals, Ontario, Canada) were made up in methanol at a concentration of $1 \mu \mathrm{g} / \mathrm{ml}$ for each chemical. To achieve nominal concentrations $(0.01,0.1,0.5 \mu \mathrm{g} / \mathrm{l})$ for each individual chemical (either fipronil or fipronil desulfinyl), 1.3, 13, and $65 \mu$ l of stock solution was added to $130 \mathrm{ml}$ of salt water (either 10 or $30 \mathrm{ppt}$ ) for each treatment, respectively. For the methanol control, $65 \mu \mathrm{l}$ of methanol alone (highest amount used in any treatment) was spiked into $130 \mathrm{ml}$ of salt water (either 10 or $30 \mathrm{ppt}$ ). This resulted in a methanol concentration of $0.05 \%$, an amount below that determined to be non-toxic to sensitive aquatic organisms and in line with that used in other toxicology studies (e.g. OECD, 2000; Brander et al., 2009; Maes et al., 2012; Brander et al., 2016b). The 130-ml 
Table 1

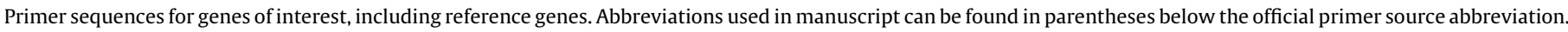

\begin{tabular}{|c|c|c|c|c|c|}
\hline $\begin{array}{l}\text { Gene of } \\
\text { interest }\end{array}$ & Abbreviation & Primers & $\begin{array}{l}\text { Average } \\
\text { efficiency }\end{array}$ & $\begin{array}{l}\text { Accession } \\
\text { number(s) }\end{array}$ & Primer source \\
\hline Vitellogenin & Taqvit (Vtg) & $\begin{array}{l}\text { Forward 5'-TGTACAGCTGAAAGGCGTGG-3' } \\
\text { Reverse 5'-CATGGGCCGAGAACAGTCA-3' }\end{array}$ & 100.26 & DQ314748.1 & $\begin{array}{l}\text { Zmora et al. } \\
(2005)\end{array}$ \\
\hline $\begin{array}{l}\text { Ecdysone } \\
\text { receptor }\end{array}$ & $\begin{array}{l}\text { Cs_tEcR } \\
(\mathrm{EcR})\end{array}$ & $\begin{array}{l}\text { Forward 5'-ACGAGAGTTGCTCCGAG-3' } \\
\text { Reverse 5'-GGTGGAAGCGATGGATGC-3' }\end{array}$ & 110.65 & $\begin{array}{l}\text { HQ630857.1 } \\
\text { HQ630858.1 } \\
\text { HQ630859.1 } \\
\text { JQ771939.1 }\end{array}$ & Novel design \\
\hline $\begin{array}{l}\text { Retinoic } \\
\text { acid } \\
\text { receptor }\end{array}$ & $\begin{array}{l}\text { Cs_tRXR } \\
(\mathrm{RXR})\end{array}$ & $\begin{array}{l}\text { Forward 5'-TCCCACACTTCACAGACCTTC-3' } \\
\text { Reverse 5'-CAGCCTGGTGAGCACTACTTC-3' }\end{array}$ & 113.27 & $\begin{array}{l}\text { HQ630860.1 } \\
\text { JQ771940.1 } \\
\text { JQ771941.1 } \\
\text { JQ771942.1 }\end{array}$ & Novel design \\
\hline $\begin{array}{l}\text { Molt } \\
\text { inhibiting } \\
\text { hormone }\end{array}$ & $\begin{array}{l}\text { CasMIH } \\
(\mathrm{MIH})\end{array}$ & $\begin{array}{l}\text { Forward 5'- } \\
\text { CACCATGAGAGTTATCAATGATGATTGT-3' } \\
\text { Reverse 5'-TCAGATCCGACCGGCCCCAA-3' }\end{array}$ & 106.55 & KJ813010.1 & $\begin{array}{l}\text { Techa et al. } \\
\text { (2015) }\end{array}$ \\
\hline $\begin{array}{l}\text { Arginine } \\
\text { kinase }\end{array}$ & $C s \_K(\mathrm{AK})$ & $\begin{array}{l}\text { Forward 5'-GCTGACGCTGCTACCATTGC-3' } \\
\text { Reverse 5'-CCAGGCTTGTCTTCTTGTCC-3' }\end{array}$ & 101.84 & AF233355.1 & Novel design \\
\hline $\begin{array}{l}\text { Elongation } \\
\text { factor } 2\end{array}$ & $\begin{array}{l}\text { D_podEF2 } \\
\text { (EF2) }\end{array}$ & $\begin{array}{l}\text { Forward 5'-AAGATGGTGCCTACCTCAGA-3' } \\
\text { Reverse 5'-CTTCATCACCTTCATGTTGTG-3' }\end{array}$ & 115.95 & $\begin{array}{l}\text { GU808334.1 } \\
\text { AY552550.1 } \\
\text { FJ790217.1 }\end{array}$ & Novel design \\
\hline
\end{tabular}

solution mixed for each treatment and salinity was then evenly split between replicate beakers. Target nominal concentrations were based on those used by Chandler et al. (2004) for Amphiascus tenuiremis with reproductive effects observed at concentrations of 0.16 and $0.22 \mu \mathrm{g} / \mathrm{l}$ fipronil treatments, and with consideration of environmentally relevant levels of fipronil detected in Californian estuaries ranging and storm run-off from 3.1 to $5.6 \mathrm{ng} / \mathrm{l}$ (Weston and Lydy, 2012) and 42 to $77 \mathrm{ng} / \mathrm{l}$ of fipronil (Gan et al., 2012), respectively. Fipronil and its photodegradation products have also been detected at high $\mathrm{ng} / \mathrm{l}$ concentrations in residential canals and holding ponds in Florida and in North Carolina wastewater effluent (Wu et al., 2015; McMahen et al., 2016).

In addition to varying the concentration of pesticide, salinity was altered to reflect the salinity range typically experienced by juveniles in an estuary. Changes in salinity were an important consideration because the solubility of organic compounds may differ depending on the salinity (Noubigh et al., 2007; Samiullah, 2012; Saranjampour et al., 2017), hence affecting fipronil and fipronil desulfinyl exposure levels. As such, juveniles were exposed to either chemical at both $30 \mathrm{ppt}$ and $10 \mathrm{ppt}$ at a temperature of $20+1{ }^{\circ} \mathrm{C}$. Crabs were exposed individually (one crab per $20 \mathrm{ml}$ beaker, 6 beakers per treatment). Exposures were conducted on individual juveniles instead of in groups to avoid cannibalism, which is common in C. sapidus (Zmora et al., 2005). Following the $96 \mathrm{hr}$ exposure, individual mass was obtained (Sartorius CPA225D Semi-Micro Balance) and carapace width was measured using calipers. Two mortalities occurred after $72 \mathrm{~h}$ of exposure in the highest concentration of fipronil $(0.5 \mu \mathrm{g} / \mathrm{l})$, no mortalities occurred in any other treatment.

\subsection{Quantitative PCR}

RNA was extracted using TRIzol reagent (Life Technologies, Carlsbad, CA) from individual juvenile crabs that had been snapfrozen and homogenized using a mortar and pestle in liquid nitrogen. Total RNA concentrations were determined using a NanoDrop ND1000 spectrophotometer (NanoDrop Technologies, Wilmington, DE). Integrity of the extracted RNA was verified via electrophoresis using a $1 \%$ agarose gel. Complementary DNA was synthesized using $1 \mu \mathrm{g}$ total RNA, using Superscript III reverse transcriptase (Life Technologies, Carlsbad, CA). The primers for C. sapidus Vtg and MIH were obtained from the primary literature (Zmora et al., 2005; Nakatsuji et al., 2006). Primers for EcR, RXR, AK, and EF2 were designed using both Primer3 (Untergasser et al., 2012) and manual examination of respective $C$. sapidus sequences (Table 1 ). Primers for EcR were designed to amplify a 212 bp region within the activation function-1 domain; the target region is invariant in all four isoforms reported by Techa and Chung (2013). Primers for RXR were designed to amplify a 165 bp region within the ligand-binding domain that is also invariant in all four isoforms reported by Techa and Chung (2013). Primers for EF2 were designed by manual examination of three decapod sequences (Table 1) aligned with Sequencher 5.0 software, Gene Codes Corporation (Ann Arbor, MI, USA). All primers were evaluated using Oligo Analyzer version 3, Integrative DNA Technologies (Coralville, Iowa, USA). Efficiencies were verified in-house for all primers immediately prior to use using $C$. sapidus RNA extracts. We then conducted qPCR using a 1:4 dilution of cDNA to measure expression levels for genes of interest (Table 1). For quantitative PCR each well contained: $1 \mu \mathrm{l} \mathrm{cDNA}$ and $9 \mu \mathrm{l}$ master mix (BioRad, Hercules, CA). The Master Mix for each gene was ultimately comprised of $52.7 \%$ SsoAdvanced Supermix (BioRad), 2.6\% forward primer, 2.6\% reverse primer, and $42.1 \%$ molecular grade (DNase free) water. Cycles were as follows: cold start, $3 \mathrm{~min}$ at $95^{\circ} \mathrm{C}, 10 \mathrm{~s}$ at $95^{\circ} \mathrm{C}$ ( 40 cycles), $15 \mathrm{~s}$ at $55-59^{\circ} \mathrm{C}$, and $30 \mathrm{~s}$ at $70^{\circ} \mathrm{C}$. A melt curve was established from 55 to $95^{\circ} \mathrm{C}$ in $0.5^{\circ} \mathrm{C}$ intervals for $10 \mathrm{~s}$ each (BioRad ${ }^{\circledR}$ iCycler 6). Manufacturer protocols from Life Technologies and BioRad were followed for cDNA synthesis and qPCR, respectively, and per methods adapted from Brander et al. (2013, 2016b) and Jeffries et al. (2015).

\subsection{Statistical approach}

All response variables (carapace width, weight, and gene expression) were analyzed using generalized linear models (GLM). Data for genes of interest (EcR, Vtg, RxR, MIH) was normalized per methods described by Livak and Schmittgen (2001) and based on approaches used in Brander et al. (2013, 2016b). Reference genes (AK, EF2) were confirmed to be stable across treatments and the geometric mean used to normalize genes of interest was calculated using the approach described by Vandesompele et al. (2002). For each analysis we used Q-Q plots and predicted-by-residual plots to verify that residuals met model assumptions of normal distribution and homoscedasticity. Generalized linear models (GLM) that included both variables (salinity [categorical] and chemical concentration [continuous]) and their interaction were used to analyze the combined effect of concentration and salinity on weight, carapace width, and gene expression (JMP 12.0). This approach (GLM 
Table 2

Actual and nominal concentrations of fipronil and fipronil desulfinyl stock solutions.

\begin{tabular}{llll}
\hline Sample & $\begin{array}{l}\text { Salt } \\
\text { content } \\
(\mathrm{ppt})\end{array}$ & $\begin{array}{l}\text { Nominal } \\
\text { concentration } \\
(\mu \mathrm{g} / \mathrm{l})\end{array}$ & $\begin{array}{l}\text { Actual } \\
\text { concentration } \\
(\mu \mathrm{g} / \mathrm{l})\end{array}$ \\
\hline Fipronil & 10 & 0.01 & 0.051 \\
Fipronil & 10 & 0.1 & 0.200 \\
Fipronil & 10 & 0.5 & 0.783 \\
Fipronil & 30 & 0.01 & 0.027 \\
Fipronil & 30 & 0.1 & 0.176 \\
Fipronil & 30 & 0.5 & 0.614 \\
Fipronil-desulfinyl & 10 & 0.01 & 0.010 \\
Fipronil-desulfinyl & 10 & 0.1 & 0.085 \\
Fipronil-desulfinyl & 10 & 0.5 & 0.377 \\
Fipronil-desulfinyl & 30 & 0.01 & 0.008 \\
Fipronil-desulfinyl & 30 & 0.1 & 0.072 \\
Fipronil-desulfinyl & 30 & 0.5 & 0.281 \\
\hline
\end{tabular}

with normal distribution) is mathematically identical to a leastsquares multiple regression with a categorical predictor or to an ANCOVA. Replicated regression approaches such as this one are recommended for evaluating dose-response relationships (versus pairwise comparisons) because of their greater statistical power (Isnard et al., 2001; Cottingham et al., 2005). All data analysis was conducted using log-adjusted (log10) average measured concentrations for each treatment. Concentrations were log-adjusted to allow the concentrations to be evenly spaced along the $x$-axis, improving model estimation. As such, the total samples size for regressions with fipronil was 45 (degrees of freedom [df]=41), and for fipronil desulfinyl was $47(\mathrm{df}=43)$. Although the experiment was designed to evaluate dose-response (continuous data), two-way ANOVAs followed by Tukey Honest Significant Difference [HSD] tests were also used to detect any significant differences between treatments; these tests had $\mathrm{df}=39$ and 37 for fipronil desulfinyl and fipronil, respectively.

\subsection{Chemical analysis of aqueous exposure solutions}

Stock solutions were analyzed to verify experimental concentrations of fipronil and fipronil desulfinyl using GC/MS. Briefly, an aliquot of $200 \mathrm{ml}$ water from each dosing trial was extracted using a modified Solid Phase Extraction (SPE) method (Doran et al., 2005) and analyzed by GC/MS. The sample extracts' final volume was $1 \mathrm{ml}$ with concentrations above the instrument limit of detections (LOD). Analyte concentrations in sample extracts were quantified using a 5-point calibration (10-125 $\mu \mathrm{g} / \mathrm{l})$ and the internal standard method (California Department of Food and Agriculture, 2008). The LOD were performed by analyzing of seven replicates at $0.01 \mu \mathrm{g} / \mathrm{l}$. The LOD for fipronil was $0.02 \mu \mathrm{g} / \mathrm{l}$ with average \% relative standard deviation (RSD) of $13 \%$. The LOD for fipronil desulfinyl was $0.01 \mu \mathrm{g} / \mathrm{l}$ with average \% RSD of $9 \%$. Method recovery was verified by spiking salt-water samples with analytes at $0.01 \mu \mathrm{g} / \mathrm{l}$ nominal concentration. The percent recoveries for spiked fipronil, and fipronil desulfinyl were greater than $90 \%$. Measured concentrations for fipronil solutions were close to nominal concentrations (Table 2), but in some cases varied enough that statistics were run using average measured concentrations instead of nominal, to improve the accuracy of results.

\subsection{Crab egg extraction for pesticide measurement}

Fipronil and fipronil desulfinyl were chosen for conducting laboratory exposures with juvenile blue crabs after fipronil desulfinyl was detected in the eggs of wild female adult $C$. sapidus collected in 2013 from an estuary off the coast of South Carolina (Santee River estuary: N $33^{\circ} 10.264^{\prime}$, W $079^{\circ} 18.208^{\prime}$ ) as part of a separate exploratory study. Following the capture of specimens and subsequent dissection, egg samples were stored at $-20^{\circ} \mathrm{C}$ until analyzed.

Extractions and analyses were performed at the United States Geological Survey (Sacramento, CA). For each sample $5 \mathrm{~g}$ of eggs were homogenized with sodium sulfate $\left(\mathrm{Na}_{2} \mathrm{SO}_{4}\right)$ and spiked with ${ }^{13} \mathrm{C}_{12}$ - $p$,p'-DDE, ${ }^{13} \mathrm{C}_{6}$-cis-permethrin, and $\mathrm{d}_{10^{-}}$ trifluralin (Cambridge Isotope, Cambridge MA) as recovery surrogates and extracted 3 times with dichloromethane (DCM) using a Dionex 200 accelerated solvent extractor (ASE) at $1500 \mathrm{psi}$ and $100^{\circ} \mathrm{C}$. Following extraction, sample extracts were dried over $\mathrm{Na}_{2} \mathrm{SO}_{4}$ and reduced to $1 \mathrm{ml}$. Extracted lipid was removed following the procedures described in Smalling et al. (2013) with an additional clean-up step where the sample was exchanged into acetonitrile, frozen for $30 \mathrm{~min}$, and then centrifuged for $3 \mathrm{~min}$ at $15,000 \mathrm{rpm}$. Extracts were analyzed for 121 pesticides and pesticide degradates (Table SI-1) using gas chromatography tandem masss spectrometry based on previously published methods (Hladik et al., 2016). The limits of detection (LOD), defined as the value greater than three times the signal-to-noise ratio, were $0.5 \mathrm{ng} / \mathrm{g}$.

\section{Results}

\subsection{Biological effects, regression}

Crabs exposed to fipronil desulfinyl at $10 \mathrm{ppt}$ had larger carapace widths with increasing concentration compared to those exposed at $30 \mathrm{ppt}$ (Fig. $1 \mathrm{~A} ; \mathrm{GLM}, p=0.0193, \mathrm{df}=3.43$ ). Independent of salinity, increasing chemical concentration had a significant positive effect on carapace width at both salinities for fipronil (Fig. 1B; GLM, $p=0.0003, \mathrm{df}=3.41)$. Crab weight also increased with concentration for both fipronil desulfinyl and fipronil (Fig. 2A; GLM, $p=0.0001$, $\mathrm{df}=3.43$; Fig. $2 \mathrm{~B}$; GLM, $p=0.0001, \mathrm{df}=3.41$ ). Weight in crabs from the fipronil desulfinyl treatment increased due to lower salinity alone (GLM, $p=0.0134, \mathrm{df}=3.43$ ) and weight also increased due to an interaction between salinity and increasing fipronil concentration (GLM, $p=0.0419$, $\mathrm{df}=3.41$ ).

Vtg expression decreased with increasing concentrations of fipronil and fipronil desulfinyl (Fig. 3B; GLM, $p=0.0344$, df = 3.41; Fig. 3A, GLM, $p=0.0320, \mathrm{df}=3.43)$. EcR expression decreased at the $30 \mathrm{ppt}$ fipronil desulfinyl exposure (Fig. 3C, GLM, $p=0.0370$, $\mathrm{df}=3.43$ ), but not at $10 \mathrm{ppt}$. Fipronil did not have a significant effect on EcR expression. No significant effects of fipronil or fipronil desulfinyl were observed for either RXR or MIH (Fig. 3E-H), although the effect of salinity on MIH expression in the fipronil desulfinyl treatment was marginally significant, with expression decreasing at $30 \mathrm{ppt}$ but not at $10 \mathrm{ppt}$ (Fig. 3F, GLM, $p=0.0565$, $\mathrm{df}=3.43$ ). There was not a significant effect of fipronil or salinity on EcR, MIH, or RXR expression (Fig. 3D, F, DH), nor was there a significant effect of fipronil desulfinyl or salinity on RXR expression (Fig. 3G). Summary statistics for all GLMS are provided in Table SI-2.

\subsection{Biological effects, two-way ANOVA}

Significant pairwise differences indicating an increase in weight were detected between the $10 \mathrm{ppt}$ control and fipronil desulfinyl $0.5 \mu \mathrm{g} / \mathrm{l}$ at both 10 and $30 \mathrm{ppt}$ (Table SI-3, Tukey HSD, $p=0.0131$, $\mathrm{df}=39 ; p=<0.001, \mathrm{df}=39$ ), fipronil desulfinyl $0.1 \mu \mathrm{g} / \mathrm{l}$ at $30 \mathrm{ppt}$ (Tukey HSD, $p=0.0026, \mathrm{df}=39$ ), and fipronil desulfinyl $0.01 \mu \mathrm{g} / \mathrm{l}$ at both 10 and $30 \mathrm{ppt}$ (Tukey HSD, $p=0.0101, \mathrm{df}=39 ; p=0.0142$, $\mathrm{df}=39$ ). Weight also significantly differed between the $30 \mathrm{ppt}$ control and fipronil desulfinyl $0.5 \mu \mathrm{g} / \mathrm{l}$ (Tukey HSD, $p=0.0118, \mathrm{df}=39$ ). Significant differences in weight were also detected between the $10 \mathrm{ppt}$ control and fipronil $0.5 \mu \mathrm{g} / \mathrm{l}$ (Table SI-3, Tukey HSD, $p=0.0003, \mathrm{df}=37$ ), fipronil 0.01 and $0.1 \mu \mathrm{g} / \mathrm{l}$ at $10 \mathrm{ppt}$ (Tukey HSD, 


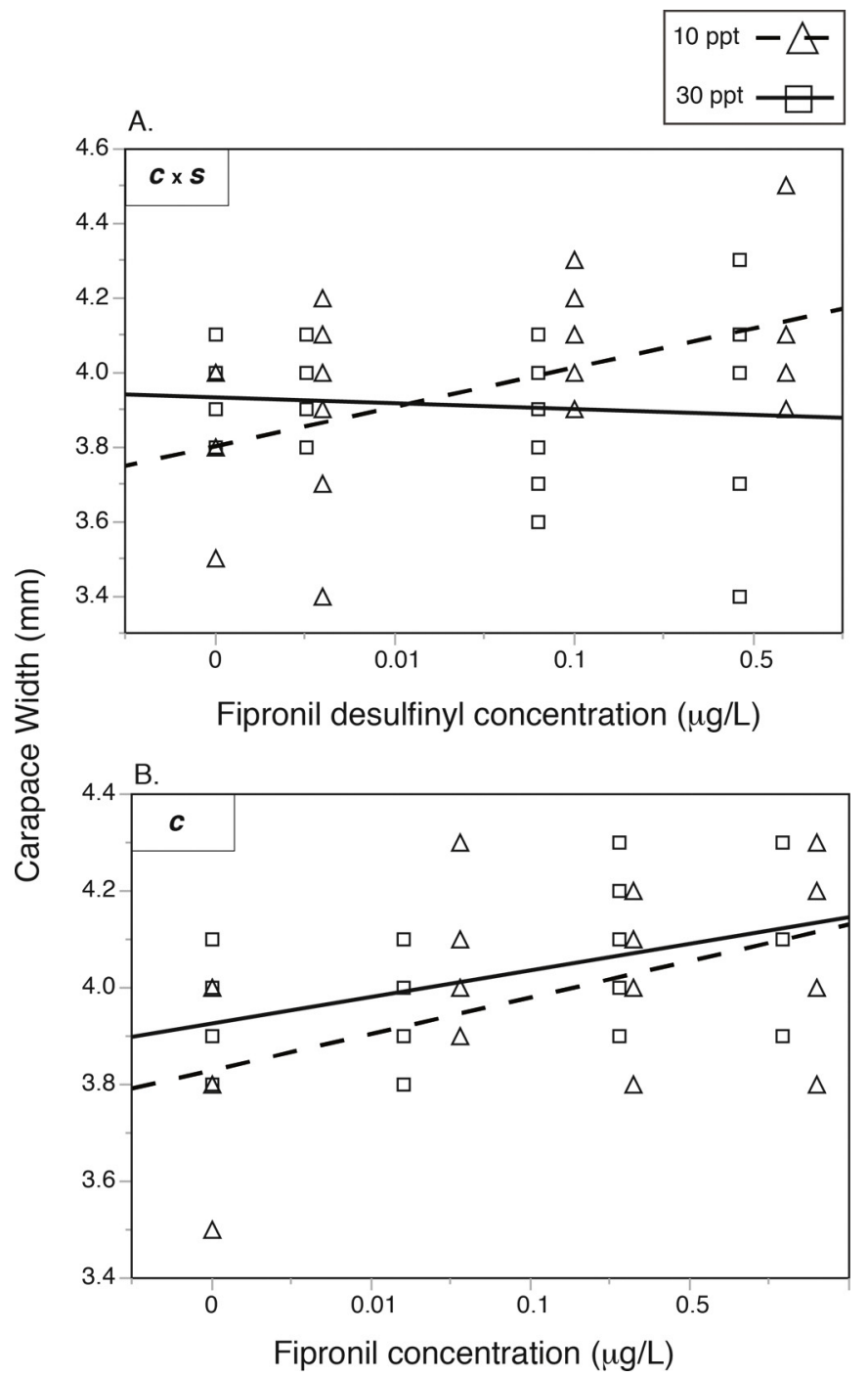

Fig. 1. (A) Effect of increasing measured concentrations of fipronil desulfinyl ( $\mu g / \mathrm{l})$, salinity, and salinity $\times$ fipronil desulfinyl on carapace width in juvenile $C$. sapidus, measured in $\mathrm{mm}(\mathrm{GLM}, \mathrm{df}=3.43)$. (B) Effect of increasing measured concentrations of fipronil $(\mu \mathrm{g} / \mathrm{l})$, salinity, and salinity $\times$ fipronil on carapace width in juvenile $C$. sapidus, measured in $\mathrm{mm}(\mathrm{GLM}, \mathrm{df}=3.41)$. Triangles denote responses at $10 \mathrm{ppt}$ salinity, squares denote responses at $30 \mathrm{ppt}$ salinity. Solid line is fit to $30 \mathrm{ppt}$ responses, the dotted line is fit to $10 \mathrm{ppt}$ responses. Significant GLM fit in both panels $(p \leq 0.05)$ is denoted by the boxed bolded $c$ (concentration effect), $s$ (salinity effect), and/or $c \times s$ (interaction effect).

$p=0.0004, \mathrm{df}=37 ; p=0.0005, \mathrm{df}=37)$, and fipronil $0.01 \mu \mathrm{g} / \mathrm{l}$ at $30 \mathrm{ppt}$ (Tukey HSD, $p=0.0024, \mathrm{df}=37$ ). Similarly, differences in weight between the $30 \mathrm{ppt}$ control and $10 \mathrm{ppt}$ fipronil $0.01 \mu \mathrm{g} / \mathrm{l}$, $0.1 \mu \mathrm{g} / \mathrm{l}$, and $0.5 \mu \mathrm{g} / \mathrm{l}$ (Table SI-3, Tukey HSD, $p=0.0029, \mathrm{df}=37$; $p=0.0033, \mathrm{df}=37 ; p=0.0020, \mathrm{df}=37$ ) were observed, as well as between the $30 \mathrm{ppt}$ control and $30 \mathrm{ppt}$ fipronil $0.01 \mu \mathrm{g} / \mathrm{l}$ (Tukey $\mathrm{HSD}, p=0.0144, \mathrm{df}=37$ ). Significant pairwise differences indicating an increase carapace width were detected between the $10 \mathrm{ppt}$ control and fipronil 0.1 and $0.5 \mu \mathrm{g} / 1$ (Table SI-3, Tukey HSD, $p=0.0144$, $\mathrm{df}=37 ; p=0.0392, \mathrm{df}=37$ ).

For gene expression, EcR had significantly lower expression in 30 ppt fipronil desulfinyl $0.5 \mu \mathrm{g} / \mathrm{l}$ compared to fipronil $0.01 \mu \mathrm{g} / \mathrm{l}$, and significantly higher expression in $30 \mathrm{ppt}$ fipronil desulfinyl $0.01 \mu \mathrm{g} / \mathrm{L}$ compared to fipronil desulfinyl $0.1 \mu \mathrm{g} / \mathrm{l}$ (Table SI-3, Tukey HSD, $p=0.0422, \mathrm{df}=39 ; p=0.0009, \mathrm{df}=39$ ). No other significant pairwise differences were detected. No significant differences were detected between the 10 and 30 ppt controls for any endpoint.

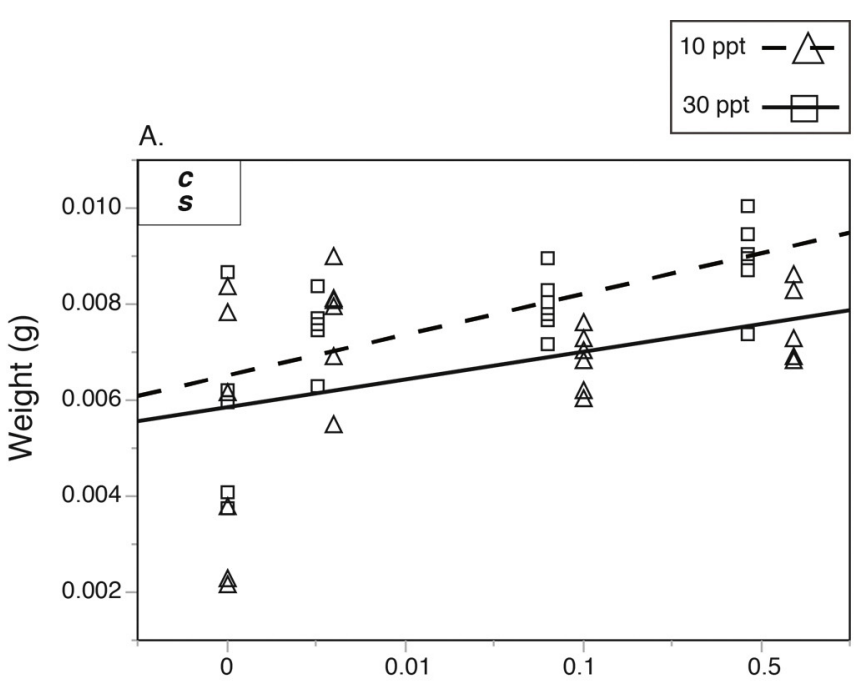

Fipronil desulfinyl concentration ( $\mu \mathrm{g} / \mathrm{L})$

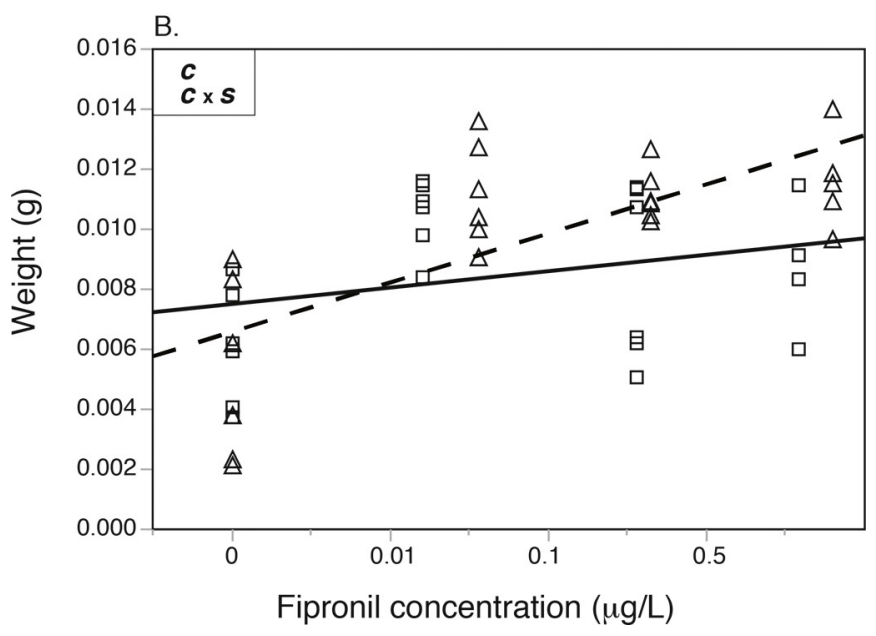

Fig. 2. (A) Effect of increasing measured concentrations of fipronil desulfinyl ( $\mu \mathrm{g} / \mathrm{l})$, salinity, and salinity $\times$ fipronil desulfinyl on weight in juvenile $C$. sapidus, measured in grams ( $\mathrm{g}$ ) (GLM, df=3.43). (B) Effect of increasing measured concentrations of fipronil $(\mu \mathrm{g} / \mathrm{l})$, salinity, and salinity $\times$ fipronil on weight in juvenile $C$. sapidus, measured in grams $(\mathrm{g})(\mathrm{GLM}, \mathrm{df}=3.41)$. Triangles denote responses at $10 \mathrm{ppt}$ salinity, squares denote responses at $30 \mathrm{ppt}$ salinity. Solid line is fit to $30 \mathrm{ppt}$ responses, the dotted line is fit to 10 ppt responses. Significant GLM fit in both panels $(p \leq 0.05)$ is denoted by the boxed bolded $c$ (concentration effect), $s$ (salinity effect), and/or $c \times s$ (interaction effect).

\section{Chemical analyses}

\subsection{Fipronil solutions}

The percent recoveries for spiked fipronil, and fipronil desulfinyl were greater than $90 \%$. Measured concentrations for fipronil solutions generally correlated with nominal concentrations with a few exceptions (Table 2). In general, measured concentrations for fipronil were somewhat higher than nominal, and measured concentrations for fipronil desulfinyl were somewhat lower. As such, all data analysis was conducted based on average measured concentrations for each treatment as the predictor variable.

\subsection{Crab egg analysis}

A summary of the pesticides analyzed for and detected in wild female adult crabs sampled from the Santee River estuary $(n=4)$ 

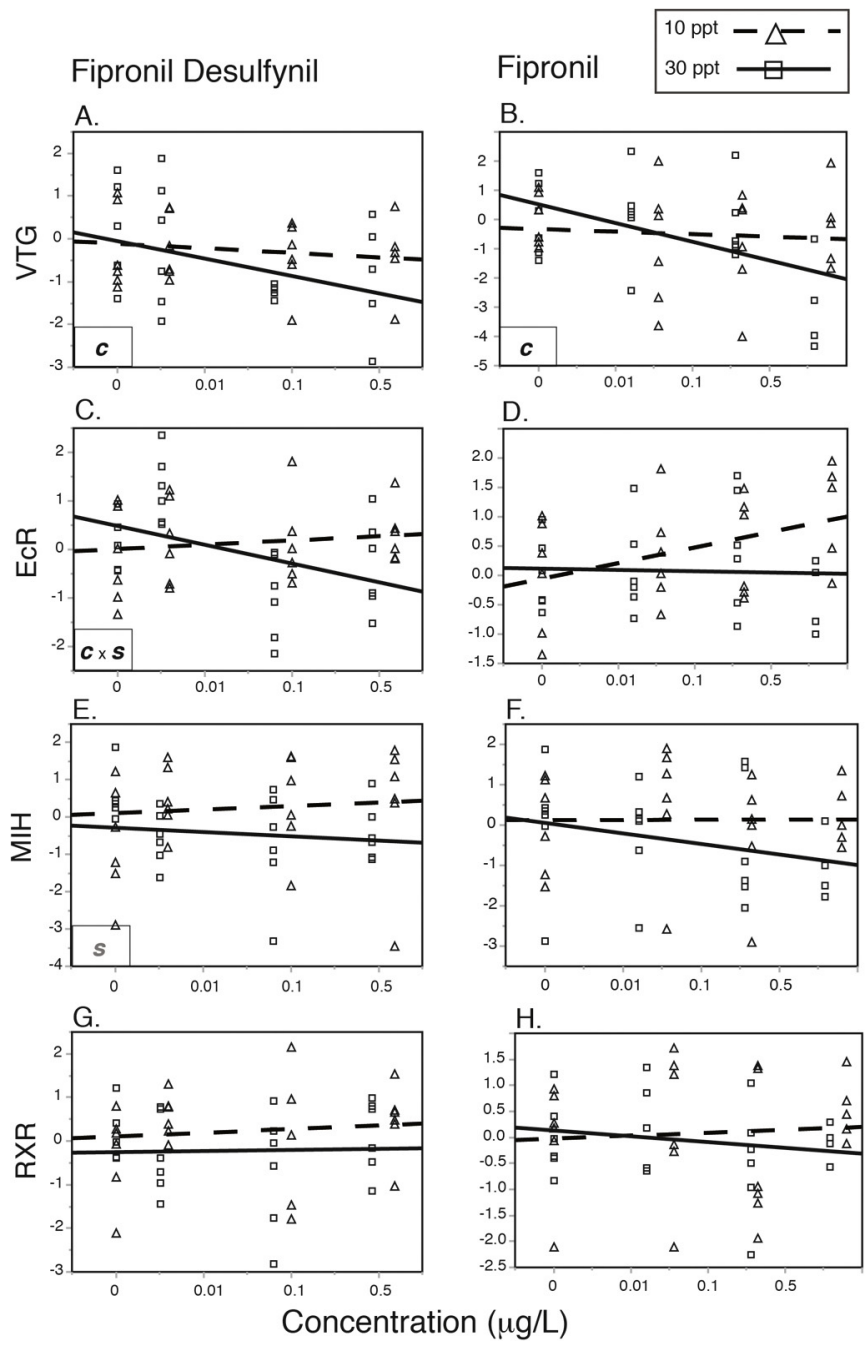

Fig. 3. (A) Effect of increasing measured concentrations of fipronil desulfinyl ( $\mu g / 1)$, salinity, and salinity $\times$ fipronil desulfinyl on Vtg gene expression $(\Delta C \mathrm{t})$ in juvenile $C$. sapidus ( $\mathrm{GLM}, \mathrm{df}=3.43$ ). (B) Effect of increasing measured concentrations of fipronil $(\mu \mathrm{g} / \mathrm{L})$, salinity, and salinity $\times$ fipronil on Vtg gene expression $(\Delta \mathrm{Ct})$ in juvenile $C$. sapidus ( $\mathrm{GLM}, \mathrm{df}=3.41$ ). (C) Effect of increasing measured concentrations of fipronil desulfinyl $(\mu \mathrm{g} / \mathrm{l})$, salinity, and salinity $\times$ fipronil desulfinyl on EcR gene expression $(\Delta \mathrm{Ct}$ ) in juvenile $C$. sapidus ( $\mathrm{GLM}, \mathrm{df}=3.43$ ). (D) Effect of increasing measured concentrations of fipronil $(\mu \mathrm{g} / \mathrm{l})$, salinity, and salinity $\times$ fipronil on EcR gene expression $(\Delta \mathrm{Ct})$ in juvenile $C$. sapidus (GLM, $\mathrm{df}=3.41)$. (E) Effect of increasing measured concentrations of fipronil desulfinyl $(\mu \mathrm{g} / \mathrm{l})$, salinity, and salinity $\times$ fipronil desulfinyl on MIH gene expression ( $\Delta \mathrm{Ct}$ ) in juvenile $C$. sapidus (GLM, df=3.43). (F) Effect of increasing measured concentrations of fipronil $(\mu \mathrm{g} / \mathrm{l})$, salinity, and salinity $\times$ fipronil on MIH gene expression ( $\Delta \mathrm{Ct}$ ) in juvenile $C$. sapidus ( $\mathrm{GLM}, \mathrm{df}=3.41)$. $(\mathrm{G})$ Effect of increasing measured concentrations of fipronil desulfinyl $(\mu \mathrm{g} / \mathrm{L})$, salinity, and salinity $\times$ fipronil desulfinyl on RXR gene expression $(\Delta \mathrm{Ct})$ in juvenile $C$. sapidus (GLM, $\mathrm{df}=3.43)$. (H) Effect of increasing measured concentrations of fipronil $(\mu \mathrm{g} / \mathrm{L})$, salinity, and salinity $\times$ fipronil on RXR gene expression $(\Delta \mathrm{Ct})$ in juvenile $C$. sapidus (GLM, $\mathrm{df}=3.41)$. Significant GLM fit in all panels $(p \leq 0.05)$ is denoted by the boxed bolded $c$ (concentration effect), $s$ (salinity effect), and/or $c \times s$ (interaction effect). Marginal significance $(p<0.06)$ is denoted by a light gray boxed letter.

during an exploratory study can be found in Table SI-3. Fipronil and fipronil desulfinyl were chosen for conducting laboratory exposures with juvenile blue crabs after the latter was detected in the eggs of two crabs at concentrations of 1.9 and $2.4 \mathrm{ng} / \mathrm{g}$.

\section{Discussion}

Relatively few toxicological studies have been performed with Callinectes sapidus (blue crab), which is important both ecologically and commercially. These results suggest that both fipronil and fipronil desulfinyl alter juvenile growth in this species and also interfere with the expression of genes that underlie growth and reproduction in decapods. Furthermore, it appears that effects at the molecular level are in some cases dependent upon the salinity at which $C$. sapidus are exposed. Juvenile $C$. sapidus exposed to both fipronil and fipronil desulfinyl increased in weight and carapace width compared to controls. Given that the experiment began when crabs were approximately 6-7 days old (1st juvenile instar), and that the molt to the 2 nd juvenile instar stage in $C$. sapidus occurs around this time (Sandoz and Rogers, 1944), it is reasonable to expect that measurable growth occurred over the 96-h exposure period. For example, it is known that $C$. sapidus can increase substantially in weight during a molting event (Cameron, 1989) and that young decapod juveniles undergo exponential growth (Miller, 2008; Ryer et al., 2016). The exact mechanism behind the increased weights of the fipronil and fipronil desulfinyl-exposed crabs is not known; however, alterations to the process of molting likely contributed. Future studies with fipronil and its degradates should be conducted over a time period that encompasses several juvenile instar stages so that the potential effects on molting activity can be quantified.

Molting in crustaceans is controlled by a group of steroid hormones known as ecdysteroids that bind to the ecdysone receptor (EcR). A recent study found that a significant increase in EcR expression in the estuarine copepod, A. tenuiremis, occurred after $30 \mathrm{~h}$ of exposure to fipronil $(0.22 \mu \mathrm{g} / \mathrm{l})$ (Gaertner et al., 2012). These findings suggest that fipronil was interfering with the EcR signaling pathway. Interestingly, in C. sapidus EcR expression decreased with increasing concentrations of fipronil desulfinyl instead of increasing with exposure to fipronil as it did in the Gaertner et al. (2012) study. Opposing results for EcR expression between these two works may be due to the difference in exposure length ( $96 \mathrm{~h}$ versus $30 \mathrm{~h}$ ) or due to a difference in the effects exerted by fipronil and fipronil desulfinyl. It is possible that after an initial upregulation of EcR during the pre-molting period that expression then declines, due the sudden drop-off in ecdysteroids that occurs in the late pre-molt stage and due to the negative feedback loop that regulates ecdysis in decapods (Dell et al., 1999; Chang and Mykles, 2011). However, this would need to be confirmed experimentally by measuring EcR expression in exposed juveniles at numerous time intervals during periods of molting. If crabs are molting more frequently, they will be soft-bodied more often increasing exposure to predators and they may be more vulnerable to chemical uptake through respiration and osmoregulation (both processes are increased following a molt) (Ryer et al., 1997). It is known, for example, that other chemicals can interfere with the molting process, and that DDT accelerates molting (Weis et al., 1992). Because gene expression can change quickly and because molting is under the control of a negative feedback loop (Chang and Mykles, 2011), both EcR and MIH would need to be measured at the gene and protein level or at different time points throughout a $96-h$ (i.e. 24 , $36,72,96)$ exposure to confirm that fipronil is directly affecting growth in $C$. sapidus via altered expression of these genes and to better understand the timing of these changes.

Similar to EcR, there was an inverse relationship between increasing concentrations of fipronil and fipronil desulfinyl, and Vtg expression. This decreased expression may underlie delays in development and reproduction as observed in studies with older juvenile or adult crustaceans (Jubeaux et al., 2012). For example, developmental delays and delayed egg extrusion in females were observed in the estuarine copepod, A. tenuiremis, following exposure to levels of fipronil $(0.22 \mu \mathrm{g} / \mathrm{l}$ and higher $)$. A population growth model employed in this study notably predicted decline at exposure levels of $0.16 \mu \mathrm{g} / \mathrm{l}$ (Chandler et al., 2004). The results of Chandler et al. (2004) are supported by findings in another study with the same species (A. tenuiremis) development is repressed after $48 \mathrm{~h}$ 
of exposure to $0.22 \mu \mathrm{g} / \mathrm{l}$ fipronil, following a spike in EcR at $30 \mathrm{~h}$ (Gaertner et al., 2012). An increase in males and a concomitant decrease in ovigerous females was observed in populations of adult grass shrimp ( $P$. pugio) exposed to fipronil in estuarine mesocosms (concentrations ranging from $0.355 \mu \mathrm{g} / \mathrm{l}$ to $5 \mu \mathrm{g} / \mathrm{l}$ ) suggesting a masculinizing effect from exposures (Wirth et al., 2004). Early life exposure to other EDCs has been shown to impair reproductive capability later in life (Brander et al., 2013), and as such these effects on Vtg expression should be further investigated in $C$. sapidus and other decapods.

Fipronil shows a $60 \%$ reduction in solubility from freshwater to seawater (Saranjampour et al., 2017). This implies that fipronil is more likely to be in the sediment and thus benthic organisms such as C. sapidus may have a greater chance of exposure. In laboratory exposures such as ours, which lack sediments, fipronil and its photodegradation products may be more likely to accumulate in tissues. Presumably, this means that fipronil and fipronil desulfinyl were less soluble in the $30 \mathrm{ppt}$ exposures than at $10 \mathrm{ppt}$. This reduction in solubility is likely due to the presence of more charged particles (salts and associated material) as water becomes more saline (Noubigh et al., 2007). This may make compounds less concentrated in the water column at higher salinities over the short term, but more persistent over the long term since such compounds would be more likely to concentrate in tissues in a laboratory experiment lacking sediment (such as ours), or a greater tendency to adsorb to sediments with which benthic organisms interact frequently in a field setting (Samiullah, 2012; Saranjampour et al., 2017). This purported change in solubility partially explain why EcR expression decreased more with increasing concentration in crabs exposed to fipronil desulfinyl at $30 \mathrm{ppt}$ versus those exposed at $10 \mathrm{ppt}$. And although there was not a significant interaction effect between fipronil and fipronil desulfinyl with salinity for Vtg expression, it appears that expression decreased at 30 ppt but remained flat at 10 ppt. Furthermore, an interaction effect between chemical and salinity was observed for weight with fipronil and for carapace width with fipronil desulfinyl, with crabs growing faster at $10 \mathrm{ppt}$. If EcR expression is lower in crabs exposed to fipronil desulfinyl at $30 \mathrm{ppt}$, this may partially explain comparatively slower growth at that salinity. The connection between endpoints associated with growth and the expression of genes that control molting, such as EcR, should be further explored with fipronil and its photodegradation products at different salinities and timepoints, given these complicated findings.

The potential increased persistence of fipronil (Saranjampour et al., 2017) and presumably its photodegradation products too, in seawater, suggests an increased vulnerability to fipronil for estuarine and marine inhabitants. This is particularly because other pesticides, such as pyrethroids and organochlorines, have been detected in the eggs of other decapods (Smalling et al., 2010). Fipronil has been detected in tail muscle tissue of crayfish, Procambarus clarkia, in response to fipronil exposures (Bedient et al., 2005; Schlenk et al., 2001) and has also been found to accumulate in the amphipod, Hyella azteca (Smith and Lizotte, 2007). Crustaceans are capable of accumulating high concentrations of fipronil, suggesting that tolerance is due to ability to detoxify or immunity to the effects of the chemical (Gunasekara et al., 2007). Similar to our observation that fipronil desulfinyl was accumulating in the eggs of wild $C$. sapidus females at low ng/g concentrations, Kröger et al. (2009) found that fipronil was capable of accumulating in lipid and muscle tissue of $P$. clarkia and $H$. azteca at concentrations ranging from 1 to $5 \mathrm{ng} / \mathrm{g}$.

Fipronil has a greater than a five-fold increase in its $K_{\text {ow }}$ moving from distilled to ASW (Saranjampour et al., 2017). This is notable because as $K_{\mathrm{ow}}$ increases so does the bioconcentration factor (BCF) of a chemical (Crosby, 1998). If these chemicals are less soluble at higher salinities (i.e. $30 \mathrm{ppt}$ ), hence resulting in greater tissue concentrations, then their effects on organisms could be greater at higher salinities as well. In the environment, male $C$. sapidus are often found in areas of lower salinity than female blue crabs (Perkins-Visser et al., 1996; Posey et al., 2005) and this may result in males being less vulnerable to phenylpyrazoles (like fipronil) due to increased solubility, and hence lower bioavailability, at lower salinities. On the other hand, females and planktonic larval forms occupying areas of higher salinity may be more vulnerable to such compounds, especially during spawning when females they are less motile due to a heavy egg burden (Hench et al., 2004).

Fipronil is used in large quantities in the Southeastern United States to control pests such as fire ants, termites, fleas, and cockroaches, and has recently been detected at $>100 \mathrm{ng} / \mathrm{l}$ levels in residential ponds and wastewater effluents (Wu et al., 2015; McMahen et al., 2016). It is notable that only fipronil desulfinyl was detected in wild $C$. sapidus eggs, this may be due exposure occurring at some distance from the source of discharge in areas not directly impacted by treated wastewater discharge (McMahen et al., 2016). However, these results and those of other studies speak to the persistence of fipronil and related photodegradation products, and the importance of looking beyond the parent compound to elucidate both environmental fate and biological effects. It is notable, for example, that fipronil desulfinyl had a greater effect on gene expression in our study than fipronil did, and that at a comparatively higher $\log K_{\text {ow }}$ than fipronil (4.0 versus 4.2 ), that desulfinyl would be more persistent.

The results herein highlight some of the potential factors involved in recently observed decreases in $C$. sapidus populations along the Eastern coast of the United States, making evident the role that EDCs may play in these declines due to induced alterations in growth and inhibition of reproduction. More targeted follow-up studies are needed to assess the exact mechanisms behind changes in gene expression and growth, and mesocosm studies that include sediments in test chambers are necessary to determine the potential for bioaccumulation and biomagnification of fipronil, fipronil desulfinyl, and other photodegradation products at differing salinities in wild populations.

\section{Acknowledgments}

Funding for the above-described study was provided in part by North Carolina Sea Grant (minigrant to SMB), the University of North Carolina Wilmington eTEAL (Experiencing Transformative Education Through Applied Learning) program, the UNCW Department of Biology and Marine Biology, and the USGS Toxic Substances Hydrology Program. We thank undergraduate researchers Chris Cantrell, Nick Jernack, and Ariel Fitzgerald for their assistance in the laboratory and with field collections. We would also like to thank Odi Zmora with the Institute of Marine and Environmental Science at the University of Maryland for providing C. sapidus megalopae. Finally, we thank the three external reviewers and one internal reviewer for their helpful and constructive comments, which greatly improved the manuscript. Any use of trade, firm, or product names is for descriptive purposes only and does not imply endorsement by the U.S. Government.

\section{Appendix A. Supplementary data}

Supplementary data associated with this article can be found, in the online version, at http://dx.doi.org/10.1016/j.aquatox.2017.02. 027. 
References

Bedient, P.B., Horsak, R.D., Schlenk, D., Hovinga, R.M., Pierson, J.D., 2005. Environmental impact of fipronil to the Louisiana crawfish industry. Environ. Forensics 6, 289-299.

Benotti, M.J., Trenholm, R.A., Vanderford, B.J., Holady, J.C., Stanford, B.D., Snyder, S.A., 2008. Pharmaceuticals and endocrine disrupting compounds in U.S. drinking water. Environ. Sci. Technol. 43, 597-603.

Bonmatin, J.M., Giorio, C., Girolami, V., Goulson, D., Kreutzweiser, D.P., Krupke, C., Liess, M., Long, E., Marzaro, M., Mitchell, E.A.D., Noome, D.A., Simon-Delso, N., Tapparo, A., 2015. Environmental fate and exposure; neonicotinoids and fipronil. Environ. Sci. Pollut. Res. 22, 35-67.

Brander, S.M., 2013. Thinking outside the box: assessing endocrine disruption in aquatic life. In: Ajuha, S. (Ed.), Monitoring Water Quality: Pollution Assessment, Analysis, and Remediation. Elsevier, Amsterdam, pp. 103-147.

Brander, S.M., Werner, I., White, J.W., Deanovic, L.A., 2009. Toxicity of a dissolved pyrethroid mixture to Hyalella azteca at environmentally relevant concentrations. Environ. Toxicol. Chem. 28, 1493-1499.

Brander, S.M., Connon, R.E., He, G., Hobbs, J.A., Smalling, K.L., Teh, S.J., White, J.W., Werner, I., Denison, M.S., Cherr, G.N., 2013. From 'omics to otoliths: responses of an estuarine fish to endocrine disrupting compounds across biological scales. PLoS ONE 8, e74251, http://dx.doi.org/10.74210.71371/journal.pone.0074251.

Brander, S., Gabler, M., Fowler, N., Connon, R., Schlenk, D., 2016a. Pyrethroid pesticides as endocrine disruptors: molecular mechanisms in vertebrates with a focus on fishes. Environ. Sci. Technol. 50, 8977-8992.

Brander, S.M., Jeffries, K.M., Cole, B.J., DeCourten, B.M., White, J.W., Hasenbein, S., Fangue, N.A., Connon, R.E., 2016b. Transcriptomic changes underlie altered egg protein production and reduced fecundity in an estuarine model fish exposed to bifenthrin. Aquat. Toxicol. 174, 247-260

California Department of Food and Agriculture, 2008. Emon-Sm-05-013: Determination of Fipronil and Metabolites in Surface Water Using Gas Chromatography/Mass Spectrometry. C. f. A. Chemistry. California Department of Food and Agriculture, Sacramento, CA.

Cameron, J.N., 1989. Post-moult calcification in the blue crab, Callinectes sapidus: timing and mechanism. J. Exp. Biol. 143, 285

Carr, J.A., Patiño, R., 2011. The hypothalamus-pituitary-thyroid axis in teleosts and amphibians: endocrine disruption and its consequences to natura populations. Gen. Comp. Endocrinol. 170, 299-312.

Chandler, G.T., Cary, T.L., Volz, D.C., Walse, S.S., Ferry, J.L., Klosterhaus, S.L., 2004 Fipronil effects on estuarine copepod (Amphiascus tenuiremis) development fertility, and reproduction: a rapid life-cycle assay in 96-well microplate format. Environ. Toxicol. Chem. 23, 117-124.

Chang, E.S., Mykles, D.L., 2011. Regulation of crustacean molting: a review and our perspectives. Gen. Comp. Endocrinol. 172, 323-330.

Connon, R.E., Geist, J., Werner, I., 2012. Effect-based tools for monitoring and predicting the ecotoxicological effects of chemicals in the aquatic environment. Sensors 12, 12741-12771.

Cottingham, K.L., Lennon, J.T., Brown, B.L., 2005. Knowing when to draw the line: designing more informative ecological experiments. Front. Ecol. Environ. 3, $145-152$.

Crosby, D.G., 1998. Environ. Toxicol. Chem. Oxford University Press, Oxford, England, U.K.

Dell, S., Sedlmeier, D., Böcking, D., Dauphin-Villemant, C., 1999. Ecdysteroid biosynthesis in crayfish Y-organs: feedback regulation by circulating ecdysteroids. Arch. Insect Biochem. Physiol. 41, 148-155.

Doran, G.S., Helliwell, S., Eberbach, P., 2005. Extraction of fipronil and thiobencarb from anaerobic water samples using solid-phase extraction. J. AOAC Int. 88 (3) 854-859.

Fulton, M.H., Moore, D.W., Wirth, E.F., Chandler, G.T., Key, P.B., Daugomah, J.W., Strozier, E.D., Devane, J., Clark, J.R., Lewis, M.A., Finley, D.B., Ellenberg, W., Karnaky, K.J., Scott, G.I., 1999. Assessment of risk reduction strategies for the management of agricultural nonpoint source pesticide runoff in estuarine ecosystems. Toxicol. Ind. Health 15, 201-214

Gaertner, K., Chandler, G.T., Quattro, J., Ferguson, P.L., Sabo-Attwood, T., 2012. Identification and expression of the ecdysone receptor in the harpacticoid copepod, Amphiascus tenuiremis, in response to fipronil. Ecotoxicol. Environ. Saf. 76, 39-45

Gan, J., Bondarenko, S., Oki, L., Haver, D., Li, J.X., 2012. Occurrence of fipronil and its biologically active derivatives in urban residential runoff. Environ. Sci. Technol. 46, 1489-1495.

Griffin, M.T., Montz, B.E., Arrigo, J.S., 2013. Evaluating climate change induced water stress: a case study of the Lower Cape Fear basin, NC. Appl. Geogr. 40, $115-128$.

Gunasekara, A.S., Truong, T., Goh, K.S., Spurlock, F., Tjeerdema, R.S., 2007. Environmental fate and toxicology of fipronil. J. Pest. Sci. 32, 189-199.

Hench, J.L., Forward, R.B., Carr, S.D., Rittschof, D., Luettich, R.A., 2004. Testing a selective tidal-stream transport model: observations of female blue crab (Callinectes sapidus) vertical migration during the spawning season. Limnol. Oceanogr. 49, 1857-1870.

Hladik, M.L., Vandever, M., Smalling, K.L., 2016. Exposure of native bees foraging in an agricultural landscape to current-use pesticides. Sci. Total Environ. 542, 469-477.

Islam, S.M., Tanaka, M., 2004. Impacts of pollution on coastal and marine ecosystems including coastal and marine fisheries and approach for management: a review and synthesis. Mar. Pollut. Bull. 48, 624-649.
Isnard, P., Flammarion, P., Roman, G., Babut, M., Bastien, P., Bintein, S., Esserméant, L., Férard, J.F., Gallotti-Schmitt, S., Saouter, E., Saroli, M., Thiébaud, H., Tomassone, R., Vindimian, E., 2001. Statistical analysis of regulatory ecotoxicity tests. Chemosphere 45, 659-669.

Jeffries, K., Brander, S., Britton, M., Fangue, N., Connon, R., 2015. Chronic exposure to low and high concentrations of ibuprofen elicit different gene response patterns in a euryhaline fish. Environ. Sci. Pollut. Res. 22, 17397-17413.

Jubeaux, G., Simon, R., Salvador, A., Queau, H., Chaumot, A., Geffard, O., 2012. Vitellogenin-like proteins in the freshwater amphipod Gammarus fossarum (Koch, 1835): functional characterization throughout reproductive process, potential for use as an indicator of oocyte quality and endocrine disruption biomarker in males. Aquat. Toxicol. 112-113, 72-82.

Key, B.P., Chung, W.K., Opatkiewicz, D.A., Wirth, F.E., Fulton, H.M., 2003. Toxicity of the insecticides fipronil and endosulfan to selected life stages of the grass shrimp (Palaemonetes pugio). Bull. Environ. Contam. Toxicol. 70, 0533-0540.

Kime, D.E., 2012. Endocrine Disruption in Fish. Springer Science \& Business Media, Dordrecht, Netherlands.

Konwick, B.J., Fisk, A.T., Garrison, A.W., Avants, J.K., Black, M.C., 2005. Acute enantioselective toxicity of fipronil and its desulfinyl photoproduct to Ceriodaphnia dubia. Environ. Toxicol. Chem. 24, 2350-2355.

Kröger, R., Lizotte, R.E., Moore, M.T., 2009. Survival, growth, and body residues of Hyalella azteca (Saussure) exposed to fipronil contaminated sediments from non-vegetated and vegetated microcosms. Bull. Environ. Contam. Toxicol. 83 , 369-373.

LeBlanc, G., 2007. Crustacean endocrine toxicology: a review. Ecotoxicology 16, 61-81.

Lee, R.F., Frischer, M.E., 2004. The Decline of the blue crab: changing weather patterns and a suffocating parasite may have reduced the numbers of this species along the Eastern seaboard. Am. Sci. 92, 548-553.

Lintelmann, J., Katayama, A., Kurihara, N., Shore, L., Wenzel, A., 2003. Endocrine disruptors in the environment. Pure Appl. Chem. 75, 631-681.

Livak, K.J., Schmittgen, T.D., 2001. Analysis of relative gene expression data using real-time quantitative PCR and the 2-CT method. Methods 25, 402-408.

Lipcius, R.N., William, T.S., 2002. Concurrent decline of the spawning stock, recruitment, larval abundance, and size of the blue crab Callinectes sapidus in Chesapeake Bay. Mar. Ecol. Progr. Ser. 226, 45-61.

Maes, J., Verlooy, L., Buenafe, O.E., de Witte, P.A.M., Esguerra, C.V., Crawford, A.D., 2012. Evaluation of 14 organitc solvents and carriers for screening applications in zebrafish embryos and larvae. PLoS ONE 7, e43850.

Mallin, M.A., Johnson, V.L., Ensign, S.H., 2009. Comparative impacts of stormwater runoff on water quality of an urban, a suburban, and a rural stream. Environ. Monit. Assess. 159, 475-491.

McMahen, R.L., Strynar, M.J., McMillan, L., DeRose, E., Lindstrom, A.B., 2016. Comparison of fipronil sources in North Carolina surface water and identification of a novel fipronil transformation product in recycled wastewater. Sci. Total Environ. 569-570, 880-887.

Miller, C.B., 2008. Copepod growth in detail: pattern similarity to decapod larvae. ICES J. Mar. Sci. 65, 332-338

Nakatsuji, T., Han, D.-W., Jablonsky, M.J., Harville, S.R., Muccio, D.D., Watson, R.D. 2006. Expression of crustacean (Callinectes sapidus) molt-inhibiting hormone in Escherichia coli: Characterization of the recombinant peptide and assessment of its effects on cellular signaling pathways in Y-organs. Mol. Cell. Endocrinol. 253, 96-104.

NCDMF, 2016. Blue Crab Fisheries Management Plan, May 2016 Revision to Amendment 2. North Carolina Division of Marine Fisheries, lang;portal.ncdenr.org $\rangle$.

Noubigh, A.A., Mgaidi, A., Abderrabba, M., Provost, E., Fürst, W., 2007. Effect of salts on the solubility of phenolic compounds: experimental measurements and modelling. J. Sci. Food Agric. 87 (5), 783-788.

OECD, 2000. Guidance Document on Aquatic Toxicity Testing of Difficult Substances and Mixtures OECD Series on Testing and Assessment Number 23 OECD Environment Directorate. OECD, Paris, pp. 53.

Oetken, M., Bachmann, J., Schulte-Oehlmann, U., Oehlmann, J.r., 2004. Evidence for Endocrine Disruption in Invertebrates, International Review of Cytology. Academic Press, Cambridge, MA, USA, pp. 1-44.

Osterberg, J.S., Darnell, K.M., Blickley, T.M., Romano, J.A., Rittschof, D., 2012. Acute toxicity and sub-lethal effects of common pesticides in post-larval and juvenile blue crabs, Callinectes sapidus. J. Exp. Mar. Biol. Ecol. 424, 425, 5-14.

Perkins-Visser, E., Wolcott, T.G., Wolcott, D.L., 1996. Nursery role of seagrass beds: enhanced growth of juvenile blue crabs. J. Exp. Mar. Biol. Ecol. 198, 155-173.

Petrovic, M., Eljarrat, E., Lopez de Alda, M.J., Barcelo, D., 2004. Endocrine disrupting compounds and other emerging contaminants in the environment: a survey on new monitoring strategies and occurrence data. Anal. Bioanal. Chem. 378, 549-562.

Posey, M.H., Alphin, T.D., Harwell, H., Allen, B., 2005. Importance of low salinity areas for juvenile blue crabs, Callinectes sapidus Rathbun, in river-dominated estuaries of southeastern United States. J. Exp. Mar Biol. Ecol. 319, 81-100.

Ridgway, J., Shimmield, G., 2002. Estuaries as repositories of historical contamination and their impact on shelf seas. Estuarine Coastal Shelf Sci. 55, 903-928.

Ryer, C.H., van Montfrans, J., Moody, K.E., 1997. Cannibalism, refugia and the molting blue crab. Mar. Ecol. Progr. Ser. 147, 77-85.

Ryer, C.H., Ottmar, M., Spencer, M., Anderson, J.D., Cooper, D., 2016 Temperature-dependent growth of early juvenile southern tanner crab Chionoecetes bairdi: implications for cold pool effects and climate change in the Southeastern Bering sea. J. Shellfish Res. 35, 259-267. 
Samiullah, Y., 2012. Prediction of the Environmental Fate of Chemicals. Springer Science and Business Media, Dordrecht, Netherlands.

Sandoz, M., Rogers, R., 1944. The effect of environmental factors on hatching, moulting, and survival of Zoea larvae of the blue crab Callinectes sapidus rathbun. Ecology 25, 216-228.

Saranjampour, P., Vebrosky, E., Armbrust, K., 2017. Salinity impacts on water solubility and n-octanol/water partition coefficients of selected pesticides and oil constituents. Environ. Toxicol. Chem., in press.

Schlenk, D., Huggett, B.D., Allgood, J., Bennett, E., Rimoldi, J., Beeler, B.A., Block, D., Holder, W.A., Hovinga, R., Bedient, P., 2001. Toxicity of fipronil and its degradation products to Procambarus sp.: field and laboratory studies. Arch. Environ. Contam. Toxicol. 41, 325-332.

Segner, H., Caroll, K., Fenske, M., Janssen, C.R., Maack, G., Pascoe, D., Schäfers, C., Vandenbergh, G.F., Watts, M., Wenzel, A., 2003. Identification of endocrine-disrupting effects in aquatic vertebrates and invertebrates: report from the European IDEA project. Ecotoxicol. Environ. Saf. 54, 302-314.

Smalling, K.L., Morgan, S., Kuivila, K.K., 2010. Accumulation of current-use and organochlorine pesticides in crab embryos from northern California, USA. Environ. Toxicol. Chem. 29, 2593-2599.

Smalling, K.L., Fellers, G.M., Kleeman, P.M., Kuivila, K.M., 2013. Accumulation of pesticides in Pacific chorus frogs (Pseudacris regilla) from California's Sierra Nevada Mountains, USA. Environ. Toxicol. Chem. 32, 2026-2034.

Smith, S., Lizotte, R.E., 2007. Influence of selected water quality characteristics on the toxicity of lamda-Cyhalothrin and gamma-Cyhalothrin to Hyallela azteca. Bull. Environ. Contam. Toxicol. 79, 548-551.

Techa, S., Chung, J.S., 2013. Ecdysone and retinoid-X receptors of the blue crab, Callinectes sapidus: cloning and their expression patterns in eyestalks and Y-organs during the molt cycle. Gene 527, 139-153.

Techa, S., Alvarez, J.V., Sook Chung, J., 2015. Changes in ecdysteroid levels and expression patterns of ecdysteroid-responsive factors and neuropeptide hormones during the embryogenesis of the blue crab, Callinectes sapidus. Gen. Comp. Endocrinol. 214, 157-166.
Turner, A., Rawling, M.C., 2001. The Influence of salting out on the sorption of neutral organic compounds in Estuaries. Water Res. 35 (18), 4379-4389.

Untergasser, A., Cutcutache, I., Koressaar, T., Ye, J., Faircloth, B., Remm, M., Rozen, S., 2012. Primer3-new capabilities and interfaces. Nucleic Acids Res, 40, e115.

Vandesompele, J., De Preter, K., Pattyn, F., Poppe, B., Van Roy, N., De Paepe, A., Speleman, F., 2002. Accurate normalization of real-time quantitative RT-PCR data by geometric averaging of multiple internal control genes. Genome Biol. 3, http://dx.doi.org/10.1186/gb-2002-1183-1187-research0034.

Viehman, S., Vander Pluym, J.L., Schellinger, J., 2011. Characterization of marine debris in North Carolina salt marshes. Mar. Pollut. Bull. 62, 2771-2779.

Walse, S.S., Morgan, S.L., Kong, L., Ferry, J.L., 2004. Role of dissolved organic matter, nitrate, and bicarbonate in the photolysis of aqueous fipronil. Environ. Sci. Technol. 38, 3908-3915.

Weis, J.S., Cristini, A., Ranga Rao, K., 1992. Effects of pollutants on molting and regeneration in Crustacea. Am. Zool. 32, 495.

Weston, D.P., Lydy, M.J., 2012. Stormwater input of pyrethroid insecticides to an urban river. Environ. Toxicol. Chem. 31, 1579-1586.

Weston, D.P., Lydy, M.J., 2014. Toxicity of the insecticide fipronil and its degradates to benthic macroinvertebrates of urban streams. Environ. Sci. Technol. 48 , 1290-1297.

Weston, D.P. Chen, D., Lydy, M.J., 2015. Stormwater-related transport of the insecticides bifenthrin, fipronil, imidacloprid, and chlorpyrifos into a tidal wetland, San Francisco Bay, California. Sci. Total Environ. 527-528, 18-25.

Wirth, E.F., Pennington, P.L., Lawton, J.C., DeLorenzo, M.E., Bearden, D., Shaddrix, B. Sivertsen, S., Fulton, M.H., 2004. The effects of the contemporary-use insecticide (fipronil) in an estuarine mesocosm. Environ. Pollut. 131, 365-371.

Wu, J., Lu, J., Lu, H., Lin, Y., Chris Wilson, P., 2015. Occurrence and ecological risks from fipronil in aquatic environments located within residential landscapes. Sci. Total Environ. 518-519, 139-147.

Zmora, O., Findiesen, A., Stubblefield, J., Frenkel, V., Zohar, Y., 2005. Large-scale juvenile production of the blue crab Callinectes sapidus. Aquaculture 244 129-139. 